\title{
Emission Characteristics of Hazardous Atmospheric Pollutants from Ultra-low Emission Coal-fired Industrial Boilers in China
}

\author{
Tao Yue ${ }^{1,2}$, Kun Wang ${ }^{1,3^{*}}$, Chenlong Wang ${ }^{1}$, Yali Tong ${ }^{1,3}$, Jiajia Gao ${ }^{1 *}$, Xiaoxi Zhang ${ }^{1}$, \\ Penglai Zuo ${ }^{1}$, Li Tong ${ }^{1,3}$, Quanming Liang ${ }^{1}$ \\ ${ }^{1}$ Department of Air Pollution Control, Beijing Municipal Institute of Labour Protection, Beijing 100054, China \\ ${ }^{2}$ State Key Laboratory of Clean Energy Utilization, Zhejiang University, Hangzhou 310058, China \\ ${ }^{3}$ Key Laboratory of Marine Environmental Science and Ecology, Ministry of Education, Ocean University of China, \\ Qingdao, 266100, China
}

\begin{abstract}
This study comprehensively investigated the emission characteristics of primary air pollutants $\left(\mathrm{PM}, \mathrm{SO}_{2}\right.$ and $\left.\mathrm{NO}_{x}\right)$ and trace elements ( $\mathrm{As}, \mathrm{Cd}, \mathrm{Cr}, \mathrm{Hg}$ and $\mathrm{Pb}$ ) from twelve coal-fired industrial boilers, nine of which were ultra-low emission (ULE) and three of which were non-ULE, based on field measurements. The concentrations, release ratios and relative enrichment factors (REFs) of the trace elements in both the coal and the bottom ash were obtained. Furthermore, the influence of atmospheric pollutant control devices (APCDs) on the emission concentrations and emission factors (EFs) of these pollutants and elements, as well as on their removal efficiencies, was analyzed. The average release ratios for $\mathrm{Hg}, \mathrm{Cr}, \mathrm{Pb}$ and $\mathrm{As}$ from the coal were $96.28 \%, 59.95 \%, 65.34 \%$ and $84.85 \%$, respectively, whereas the average overall removal efficiencies for PM, $\mathrm{SO}_{2}, \mathrm{NO}_{x}, \mathrm{Hg}, \mathrm{Cr}, \mathrm{Pb}$ and As with the APCD configurations of the ULE coal-fired industrial boilers were 99.5\%, 95.9\%, $81.0 \%, 95.6 \%, 95.6 \%, 99.3 \%$ and $96.0 \%$, respectively. Using selective non-catalytic reduction (SNCR), and a hybrid of selective non-catalytic reduction and selective catalytic reduction (SNCR-SCR) in the ULE boilers, the EFs of the $\mathrm{NO}_{x}$ were $5.5 \times 10^{-1} \mathrm{~kg} \mathrm{t}^{-1}$ and $4.9 \times 10^{-1} \mathrm{~kg} \mathrm{t}^{-1}$, respectively. Overall, the removal efficiencies for $\mathrm{NO}_{x}$ and $\mathrm{Hg}$ were 2.1 and 2.8 times higher, respectively, with the ULE than the non-ULE coal-fired industrial boilers, which was mainly attributable to the higher denitrification efficiency, higher dedusting efficiency and higher liquid/gas (L/G) desulfurization ratio of the ULE boilers.
\end{abstract}

Keywords: Ultra-low emission; Coal-fired industrial boilers; Emission characteristics; Trace elements; Relative enrichment factors.

\section{INTRODUCTION}

Coal-fired industrial boilers are the general power equipment in China and the important consumers of coal, consuming about 700 million tons of coal, which accounted for $13.5 \%$ of the total coal consumption in China in 2015 (NBS, 2016). The emission of $\mathrm{PM}, \mathrm{SO}_{2}$ and $\mathrm{NO}_{x}$ from coal-fired industrial boilers were 1.6 million tons, 7.2 million tons and 2.7 million tons in 2011, respectively, which is responsible for releasing large quantities of not only primary air pollutants but also trace elements into the atmosphere (MEP, 2011, 2013; Zhao et al., 2010; Tian et al., 2015, 2018). Therein, trace elements in coal were volatilized into metallic vapor or sub-micrometer particles at high temperature in the furnace room and emitted

\footnotetext{
${ }^{*}$ Corresponding author.

Tel./Fax: 86-10-63524193

E-mail address: wkty@mail.bnu.edu.cn (K. Wang);

jiajia11757@126.com (J. Gao)
}

to the environment by adsorption onto the fly ash or along with flue gas (Lin et al., 2005).

China still has numerous coal-fired industrial boilers, and the combustion efficiency and atmospheric pollutant control devices (APCDs) are still lagging behind. Environmental statistics showed that only $19 \%$ and $1.4 \%$ of coal-fired industrial boilers were equipped with denitrification devices and flue gas desulfurization (FGD) devices by the end of 2015 in China (NEMC, 2016). At present, coal-fired industrial boilers in China are dominated by small-capacity boilers. Grate-fired (GF) boilers, circulating fluidized-bed (CFB) boilers and pulverized coal (PC) boilers are the major boiler types. By 2015, GF boilers (chain grate-fired boilers, stokerfired boilers and other grate-fired boilers) and CFB boilers accounted for $69 \%$ and $21 \%$ of the capacity in coal-fired industrial boilers, respectively (NEMC, 2016), where CFB boilers had been rapidly developed since the 1960s in China as a clean boiler type for $\mathrm{SO}_{2}$ and $\mathrm{NO}_{x}$ emission control (Duan et al., 2012).

With the enhancement of the environmental management requirement, coal-fired power plants in China have already 
completed the ultra-low emission (ULE) retrofit. Some coalfired industrial boilers have implemented the ULE retrofit by adopting the same APCDs applied in coal-fired power plants to execute the ultra-low emission standards, such as hybrid of selective non-catalytic reduction and selective catalytic reduction (SNCR-SCR) for denitrification, more efficient wet flue gas desulfurization (WFGD) for desulfurization, and wet electrostatic precipitator (WESP) after WFGD systems for removal of PM and secondary PM produced by wet desulfurization (Zhu et al., 2014; Yao et al., 2019). In August 2015, Shandong Province required the in-use coal-fired industrial boilers to be carried out ULE retrofit to meet the ULE limits of $10 \mathrm{mg} \mathrm{m}^{-3}, 50 \mathrm{mg} \mathrm{m}^{-3}$, and $200 \mathrm{mg} \mathrm{m}^{-3}$ for $\mathrm{PM}, \mathrm{SO}_{2}$ and $\mathrm{NO}_{x}$, respectively, under the $\mathrm{O}_{2}$ content of $9 \%$ (SEPD, 2015). In November 2018, the Chinese government required that the emission concentration of atmospheric pollutants from newly built coal-fired boilers in the key air pollution control region must meet the ULE limits (MEE, 2018). These stringent environmental management requirements will have significant impacts on the emission characteristics of atmospheric pollutants from coal-fired industrial boilers by altering the boiler types and levels of pollutant control devices.

Several studies have conducted on emission level and removal efficiency of hazardous air pollutants from ULE and non-ULE coal-fired power plants (Zhang et al., 2008; Zhao et al., 2017; Zheng et al., 2017). Wu et al. $(2018,2020)$ established an integrated emission factors (EFs) database of size-fractioned particulate matter (PM) for typical ULE technical routes installed in coal-fired power plant. Zheng et al. (2017) investigated partitioning of hazardous trace elements from ULE coal-fired power plants. Zhang et al. (2019) investigated the removal efficiency of $\mathrm{SO}_{3}$ in ULE coal-fired power plants. Compared with coal-fired power plant, there are few studies on coal-fired industrial boiler. Previous studies are mainly focus on emission characteristics of primary air pollutants from non-ULE coal-fired industrial boiler. The Electrical Low-Pressure Impactor (ELPI) was applied to investigate the emission characteristics of sizefractioned PM of industrial boilers (Cornette et al., 2020). Zhao et al. (2014) studied the $\mathrm{PM}_{2.5}$ emission characteristics of a CFB boiler equipped with fabric filters (FFs). Li et al. (2018, 2019) obtained $\mathrm{NO}_{x}, \mathrm{PM}, \mathrm{SO}_{2}$, and VOCs EFs of coal-fired boilers from more than 91 enterprises related to coal washing, iron-steel production, lime and gypsum making, coking, and cement industries. Ruan et al. (2019) studied the PM emission characteristics from two ULE coal-fired industrial boilers in Xi'an, China, and the PM removal efficiency of the FFs for a chain-grate boiler and a CFB boiler were obtained. Yue et al. (2018) evaluated the environmental impacts of coal-fired industrial boilers in Beijing, based on a comprehensive emission inventory established in this study. Comprehensive researches on the removal efficiency and EFs of primary air pollutants and trace elements from coal-fired industrial boilers, especially for ULE boilers in China, are still quite limited.

With the stricter requirement for pollutants emission from coal-fired industrial boilers, the boiler types and APCDs of coal-fired industrial boilers in China have been changed significantly. However, due to the limited field measurement data of primary hazardous atmospheric pollutants from coalfired industrial boilers in the context of current control technology, the true emission characteristics of primary air pollutants and trace elements are unclear.

In this study, we presented comprehensive investigations of the emission characteristics of primary air pollutants (PM, $\mathrm{SO}_{2}$ and $\mathrm{NO}_{x}$ ) and trace elements ( $\mathrm{As}, \mathrm{Cd}, \mathrm{Cr}, \mathrm{Hg}$ and $\mathrm{Pb}$ ) by the field measurements of nine ULE coal-fired boilers. The data obtained from this study is valuable for systematically understanding the emission characteristics of primary air pollutants and trace elements from coal-fired industrial boilers with ULE.

\section{METHODOLOGY}

\section{Unit Description and Test Conditions}

Nine typical coal-fired industrial boilers after ULE retrofit were selected for conducting field tests considering the boiler capacity, boiler types and APCDs. The basic information of the nine ULE coal-fired industrial boilers is shown in Table 1 as the \#1-9 units. To compare the emission characteristics of primary air pollutants and trace elements of ULE and nonULE coal-fired industrial boilers, three coal-fired industrial boilers without ULE retrofit were chosen in this study. The basic information of the three coal-fired industrial boilers without ULE retrofit is shown in Table 1 as the \#10, \#11 and \#12 units.

GF boilers and CFB boilers are two kinds of industrial boilers most widely used in China. Therefore, the nine ULE coal-fired industrial boilers selected in this study include five GF boiler units and four CFB boiler units. The \#5 unit was equipped with SNCR, while the \#6 and \#9 units were equipped with hybrid SNCR-SCR, which is usually equipped in coal-fired industrial boilers to meet the $\mathrm{NO}_{x}$ emission limit. Like the \#1-4 units, the combination of low- $\mathrm{NO}_{x}$ burner technology (LNB) and SNCR is usually applied in CFB boilers, because of the calcium poisoning of de- $\mathrm{NO}_{x}$ catalysts on SCR and the space limit after furnace (Shang et al., 2013; Wang et al., 2017; Zheng et al., 2017). Meanwhile, in order to adapt to the low-temperature flue gas emitted from coalfired industrial boilers, the oxidation denitrification (OD) technology using $\mathrm{NaClO}_{2}$ or $\mathrm{O}_{3}$ as the oxidant and sorbent to remove $\mathrm{NO}_{x}$, has been used in recent years (Chien and Chu, 2000), such as the \#7 and \#8 units in this study. In terms of dust removal technologies, the \#2, \#3 and \#4 units used electrostatic fabric filters (ESP-FFs) + WESP and the other seven boilers used fabric filters (FFs) + WESP. FFs and electrostatic precipitator (ESP) are two of the most effective and widely used post-combustion dust removal technologies. It was found that WESP had a good removal efficiency (7.72-94.41\%) for ultrafine particles (Ruan et al., 2019), and it is usually installed as a final APCD to ensure that the emission of air pollutants meet the ULE standards. WFGD (limestone-gypsum, natrium alkali, magnesia) is also commonly used in coal-fired industrial boilers. During the tests, the boilers and APCDs were all operated under normal conditions. 


\section{Sampling Methods}

Sampling and testing were strictly in accordance with the relevant standards and technical criterion for the stationary sources (MEP, 1996, 2017). The APCDs' configuration and sampling points are presented in Table 1. The management of coal-fired industrial boilers is generally not as good as coal-fired power plants. The sampling port diameter and platform space of coal-fired industrial boilers cannot always meet the test requirements, so the real field condition is not always available for sampling at the inlet and outlet of all the APCDs. In this study, there were no sampling points for the denitrification equipment.

The sampling points are shown in Fig. 1. PM was sampled by the PM sampler (3012H-D; Qingdao LaoYing Environmental Science and Technology, Co., Ltd.) equipped with the low-concentration membrane sampling tube. Gaseous pollutants $\left(\mathrm{NO}_{x}\right.$ and $\left.\mathrm{SO}_{2}\right), \mathrm{O}_{2}$ content, flue gas velocity and the temperature were tested by the gas analyzer (testo 350 ; Testo). Trace elements ( $\mathrm{Hg}, \mathrm{As}, \mathrm{Pb}, \mathrm{Cd}$ and $\mathrm{Cr}$ ) in the flue gas were sampled by the sampler (C-5000 series; ESC) following EPA Method 29 and analyzed by atomic fluorescence spectrophotometry (AFS) and inductively coupled plasma mass spectrometry (ICP-MS). The coal and bottom ash were collected as solid samples for all plants and the contents of trace elements $(\mathrm{Hg}, \mathrm{As}, \mathrm{Pb}, \mathrm{Cd}$ and $\mathrm{Cr}$ ) in the coal and bottom ash were also analyzed by AFS and ICP-MS. The detection limits of $\mathrm{Hg}, \mathrm{As}, \mathrm{Pb}, \mathrm{Cd}$ and $\mathrm{Cr}$ were $0.002 \mathrm{mg} \mathrm{kg}^{-1}$, $0.5 \mathrm{mg} \mathrm{kg}{ }^{-1}, 2.1 \mathrm{mg} \mathrm{kg}{ }^{-1}, 0.6 \mathrm{mg} \mathrm{kg}^{-1}$ and $1.0 \mathrm{mg} \mathrm{kg}$, respectively. Pollutant concentrations were converted to the values under the $\mathrm{O}_{2}$ content of $9 \%$, as required by relevant criterion (MEP, 2014).

\section{Analytical Methods}

Trace Elements

The mass balance method is calculated by normalizing the concentration of each trace element for the entire process. It is widely used to investigate the EFs and removal efficiency for trace elements (Zhang et al., 2016; Zheng et al., 2017; $\mathrm{Wu}$ et al., 2018). In this study, based on the inlet and outlet concentration of trace elements for APCDs, the EFs and removal efficiency of trace elements were calculated by Eqs. (1) and (2):

$$
\begin{aligned}
& E F_{\text {te }}=C_{t_{\text {te }} \text { fluegas }} \times \frac{\left(21-\varphi\left(\mathrm{O}_{2}\right)\right)}{1000 \times\left(21-\varphi^{\prime}\left(\mathrm{O}_{2}\right)\right)} \times V \\
& \eta_{t e}=1-\left(E F_{\text {te }} /\left(R_{E C} \times C_{t_{\text {te_coal }}}\right)\right)
\end{aligned}
$$

where $E F_{t e}$ is the emission factor for trace elements, $\mathrm{g} \mathrm{t}^{-1}$; $C_{t e}$ fluegas is the concentration of trace elements in the flue gas, $\mu \mathrm{g} \mathrm{m}^{-3} ; C_{t e}$ coal is the concentration of trace elements in the feed coal, mg kg-1 $V$ is the volume of the flue gas per unit of fuel consumption, $\mathrm{m}^{3} \mathrm{~kg}^{-1} ; R_{E C}$ is the release ratio for trace elements, $\% ; \varphi\left(\mathrm{O}_{2}\right)$ is the reference oxygen content where 9\% was applied according to GB13271-2014; and $\varphi^{\prime}\left(\mathrm{O}_{2}\right)$ is the oxygen content measured by the gas analyzer.

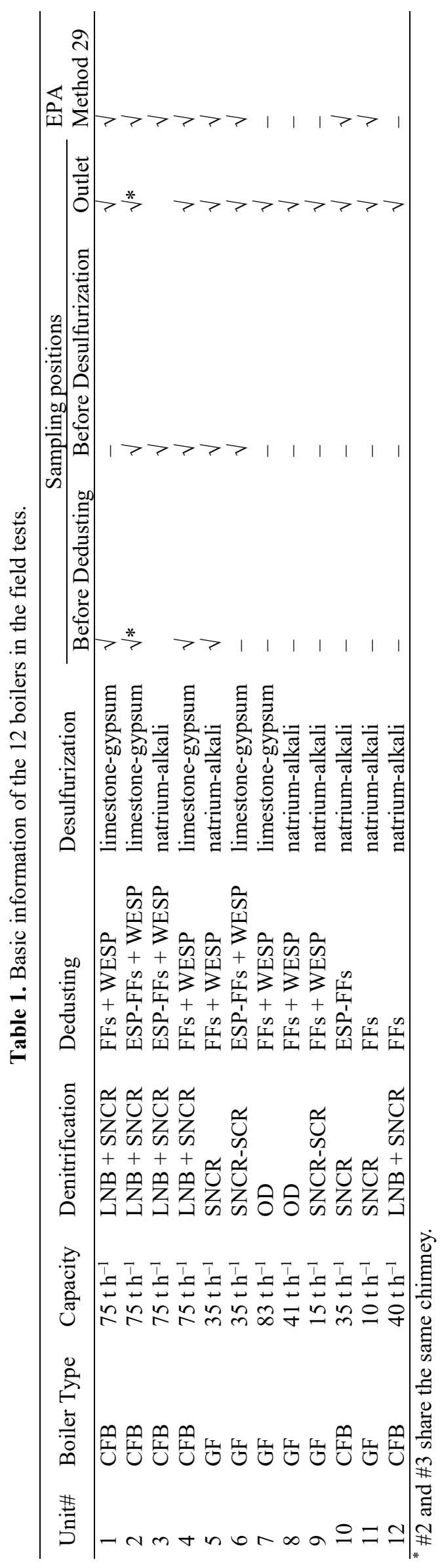




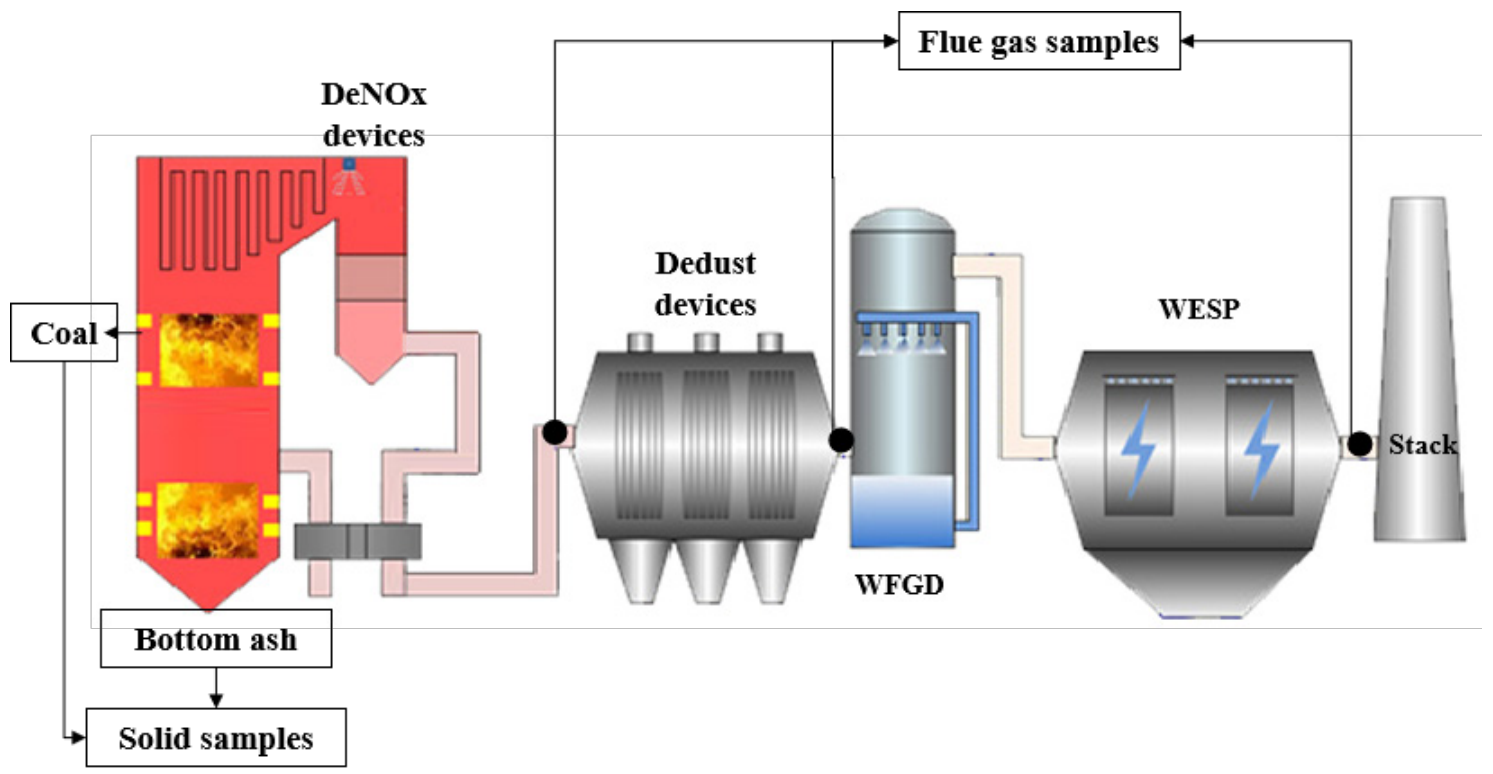

Fig. 1. APCDs' configurations and sampling points.

Because of the volatility of different trace elements at high temperature in the furnace, the release characteristics of trace elements are different. The term "release ratio" represents the proportion of trace elements in the feed coal released to the flue gas and fly ash, which can be calculated by Eq. (3):

$R_{E C}=1-\frac{C_{\text {bottom ash }} \times M_{\text {bottom ash }}}{C_{\text {coal }}}$

where $R_{E C}$ represents the release ratio of trace elements from the coal to the flue gas and fly ash, $\% ; C_{\text {bottom ash }}$ represents the concentration of trace elements in the bottom ash, $\mathrm{mg} \mathrm{kg}^{-1}$; $C_{\text {coal }}$ represents the concentration of trace elements in the feed coal, $\mathrm{mg} \mathrm{kg}^{-1}$; and $M_{\text {bottom ash }}$ represents the mass of bottom ash produced by coal combustion, $\mathrm{kg} \mathrm{kg}^{-1}$, which can be estimated by the ash content in the feed coal by Eq. (4):

$M_{\text {bottom ash }}=k_{\text {boiler type }} \times A_{\text {coal }}$

where $A_{\text {coal }}$ represents the ash content in the coal, \%, and $k_{\text {boiler type }}$ represents the production factor of the bottom ash from different boiler type. For CFB boilers, $k_{\text {boiler type }}=5.25$, and for GF boilers, $k_{\text {boiler type }}=9.24$ (CNPSS, 2011).

In addition, in order to investigate the partitioning behavior of trace elements from the feed coal into the bottom ash, the term "relative enrichment factors" was introduced to describe the behavior of trace elements remaining in the bottom ash (Meij, 1994), as shown in Eq. (5). Generally, REFs presented the partitioning of trace elements after coal combustion and a high REF means a strong enrichment capacity for the trace element in the ash (Bhattacharyya et al., 2009; Zheng et al., 2017):

$R E F S=\frac{C_{a s h}}{C_{\text {coal }}} \times \frac{A_{\text {coal }}}{100}$ where $C_{\text {ash }}$ represents the concentration of trace elements in the bottom ash, $\mathrm{mg} \mathrm{kg}^{-1} ; C_{\text {coal }}$ represents the concentration of trace elements in the feed coal, $\mathrm{mg} \mathrm{kg}^{-1}$; and $A_{\text {coal }}$ represents the ash content in the feed coal, $\%$.

\section{Primary Pollutants}

The EFs of $\mathrm{PM}, \mathrm{SO}_{2}$ and $\mathrm{NO}_{x}$ from coal-fired industrial boilers can be calculated by Eq. (6) (Zhao et al., 2010; CNPSS, 2011):

$E F_{p}=C_{p} \times \frac{\left(21-\varphi\left(\mathrm{O}_{2}\right)\right)}{1000 \times\left(21-\varphi^{\prime}\left(\mathrm{O}_{2}\right)\right)} \times V$

where $E F_{p}$ is the emission factor of pollutant $p, \mathrm{~kg} \mathrm{t}^{-1} ; C_{p}$ is the emission concentration of pollutant $p$ in the flue gas, $\mathrm{mg} \mathrm{Nm} \mathrm{Nm}^{-3}$; and $V$ is the volume of the flue gas per unit of fuel consumption, $\mathrm{m}^{3} \mathrm{~kg}^{-1}$.

The flue gas volume is mainly affected by the lower heating value of coals, and bituminous is the main coal type of coalfired industrial boilers in China. $V$ in Eq. (6) and Eq. (4) can be calculated by Eq. (7) (Zhao et al., 2010):

$$
\begin{aligned}
V & =1.04 \times \frac{Q_{L}}{4187}+0.77+1.0161 \times(\alpha-1) \\
& \times\left(0.251 \times \frac{Q_{L}}{1000}+0.278\right)
\end{aligned}
$$

where $Q_{L}$ is the lower heating value, $\mathrm{kJ} \mathrm{kg}^{-1}$, and $\alpha$ is the excess air coefficient where 1.75 was applied according to GB13271-2014. Meanwhile, the removal efficiency for APCDs is calculated by Eq. (8):

$\eta=1-\left(C_{\text {outlet }} / C_{\text {inlet }}\right)$

where $C_{\text {outlet }}$ and $C_{\text {inlet }}$ are the pollutant concentrations in the 
flue gas from the outlet and inlet of each APCD, respectively, $\mathrm{mg} \mathrm{Nm}{ }^{-3}$.

\section{RESULTS}

\section{Enrichment Characteristics of Trace Elements in the Feed Coal and Bottom Ash}

The REFs of trace elements in the bottom ash are shown in Tables S1 and S2. Because the concentrations of $\mathrm{Cd}$ in the feed coal and bottom ash were below the detection limit, $\mathrm{Cd}$ was not discussed in this study.

Fig. 2 shows the distribution of trace elements content in the feed coal and bottom ash. The average content of $\mathrm{Cr}$ and $\mathrm{Pb}$ were $6.18 \mathrm{mg} \mathrm{kg}^{-1}$ and $7.43 \mathrm{mg} \mathrm{kg}^{-1}$ in the feed coal, respectively, which were $71.8-74.6 \%$ lower than those in bottom ash. The average content of As in feed coal was $6.92 \mathrm{mg} \mathrm{kg}^{-1}$, which was 1.5 times higher than that in bottom ash. While the average content of $\mathrm{Hg}$ in feed coal was $0.048 \mathrm{mg} \mathrm{kg}^{-1}$ in feed coal, higher than $0.007 \mathrm{mg} \mathrm{kg}^{-1}$ in bottom ash. This can be explained by the REFs as follows.

Meij and Winkel (2007) classified the trace elements into three classes based on their behavior during the combustion in the boiler with their REFs. In this study, the REFs of $\mathrm{Cr}$, $\mathrm{Pb}$ and $\mathrm{As}$ were less than 0.7 , classified as Class II. Cr, $\mathrm{Pb}$ and As were volatile in the boiler, but they were completely condensed in ESP on the ash particles. $\mathrm{Cr}, \mathrm{Pb}$ and $\mathrm{As}$ originally existed in the vapor phase and had no chance to be condensed on the bottom ash. The REFs of $\mathrm{Hg}$ was very small $(<<1)$ in the bottom ash, and $\mathrm{Hg}$ was classified as Class III, which manifested that $\mathrm{Hg}$ tended to remain in the flue gas, resulting in the emission of high concentrations of $\mathrm{Hg}$ into the atmosphere.

\section{EFs and Removal Efficiency of Trace Elements}

The boiling points of $\mathrm{Hg}, \mathrm{Cd}, \mathrm{Cr}, \mathrm{Pb}$ and $\mathrm{As}$ are $356^{\circ} \mathrm{C}$, $767^{\circ} \mathrm{C}, 2672^{\circ} \mathrm{C}, 1749^{\circ} \mathrm{C}$ and $613^{\circ} \mathrm{C}$, respectively. Researchers have found that the combustion temperature in the furnace and the composition of the flue gas have the effect on the proportion of trace elements in the bottom ash (Hiraoka et al., 1980; Gerstle and Albrinck, 1982; Chang et al., 2000; Zheng et al., 2017). Since trace elements in some feed coal and bottom ash samples were under the detected limits, the release ratio of available data has been calculated, as shown in Table S3.

Due to the optimum desulfurization temperature (generally $850-900^{\circ} \mathrm{C}$ ) and strong turbulent motion in CFB boilers, the emission characteristics of trace elements for CFB and GF boilers are different (Xu et al., 2004). The average release ratio of $\mathrm{Hg}, \mathrm{Cr}, \mathrm{Pb}$ and $\mathrm{As}$ in CFB boilers were 97.87\%, $57.94 \%, 52.41 \%$ and $86.64 \%$, respectively, while the average release ratio of $\mathrm{Hg}, \mathrm{Cr}, \mathrm{Pb}$ and $\mathrm{As}$ in $\mathrm{GF}$ boilers were $95.14 \%, 62.96 \%, 86.90 \%$ and $81.27 \%$, respectively, as shown in Fig. 3. The average release ratio of $\mathrm{Hg}$ and $\mathrm{As}$ in CFB boilers were higher than that in GF boilers, and the range of release ratio for $\mathrm{Cr}$ and $\mathrm{Pb}$ in CFB boilers was larger than that in GF boilers.

APCDs have co-benefits to trace elements, as most of the trace elements were enriched in the fly ash (Zhang et al., 2017; Zheng et al., 2017). To obtain the EFs and removal efficiency of trace elements, the concentrations of trace elements in the feed coal, the bottom ash and the flue gas were analyzed. Fig. 4 shows the distribution of trace elements' concentrations for $\mathrm{Hg}, \mathrm{Cr}, \mathrm{Pb}$ and $\mathrm{As}$ in the flue gas at outlet for six ULE coal-fired industrial boilers (\#1-6), which were $0.02-0.42 \mu \mathrm{g} \mathrm{m}^{-3}, 5.92-20.01 \mu \mathrm{g} \mathrm{m}^{-3}, 0.91-6.61 \mu \mathrm{g} \mathrm{m}^{-3}$ and $0.63-11.39 \mu \mathrm{g} \mathrm{m}^{-3}$, respectively. Besides, the Cd concentration in $\# 8$ was $0.02 \mu \mathrm{g} \mathrm{m}^{-3}$.

Table 2 shows the EFs and removal efficiency of $\mathrm{Hg}, \mathrm{Cr}$, $\mathrm{Pb}$ and $\mathrm{As}$. The average EFs of $\mathrm{Hg}, \mathrm{Cr}, \mathrm{Pb}$ and $\mathrm{As}$ for ULE coal-fired industrial boilers were $0.0007 \mathrm{~g} \mathrm{t}^{-1}, 0.135 \mathrm{~g} \mathrm{t}^{-1}$, $0.038 \mathrm{~g} \mathrm{t}^{-1}$ and $0.055 \mathrm{~g} \mathrm{t}^{-1}$, respectively, while the average EFs of $\mathrm{Hg}, \mathrm{Cr}, \mathrm{Pb}$ and As for non-ULE coal-fired industrial boilers were $0.006 \mathrm{~g} \mathrm{t}^{-1}, 0.09 \mathrm{~g} \mathrm{t}^{-1}, 0.045 \mathrm{~g} \mathrm{t}^{-1}$ and $0.015 \mathrm{~g} \mathrm{t}^{-1}$, respectively. $E F_{H g}$ of the ULE coal-fired industrial boilers was approximately $83 \%$ lower than that of the non-ULE coal-fired industrial boilers. The overall removal efficiency of $\mathrm{Hg}, \mathrm{Cr}, \mathrm{Pb}$ and $\mathrm{As}$ for ULE boilers were 90.8-99.2\%,

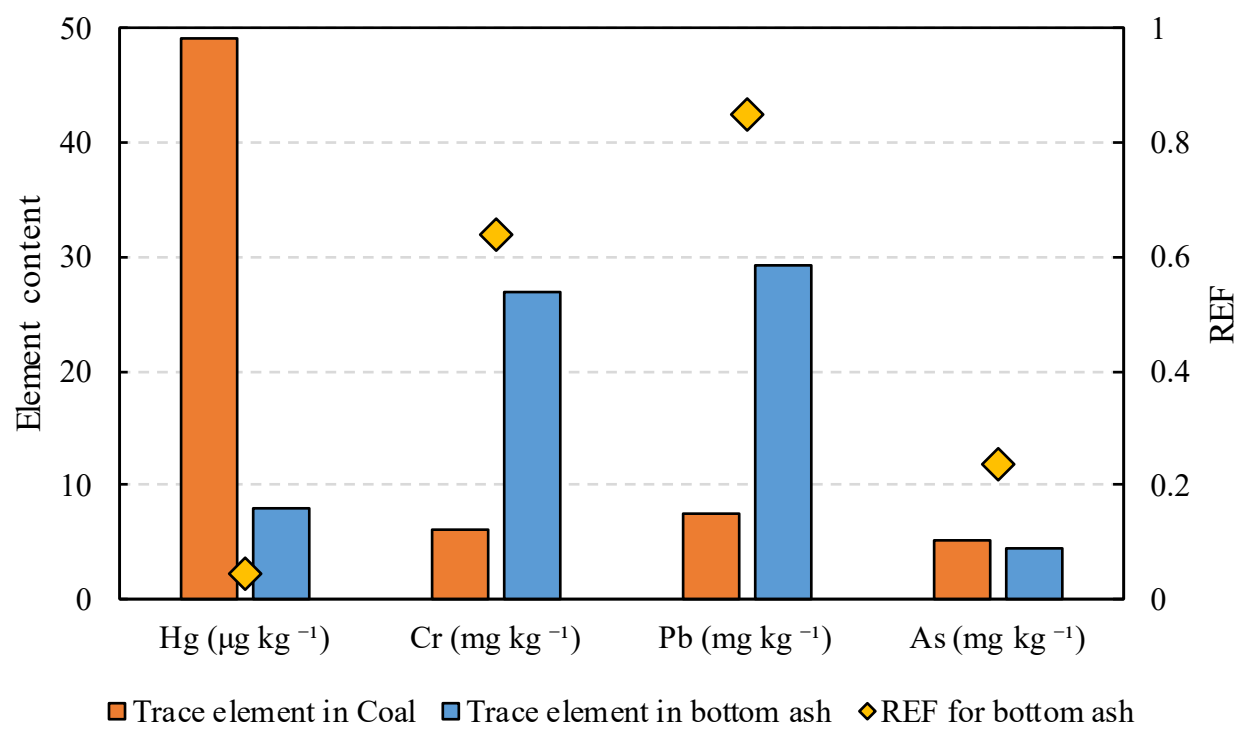

Fig. 2. Average trace element content in the feed coal and bottom ash. 


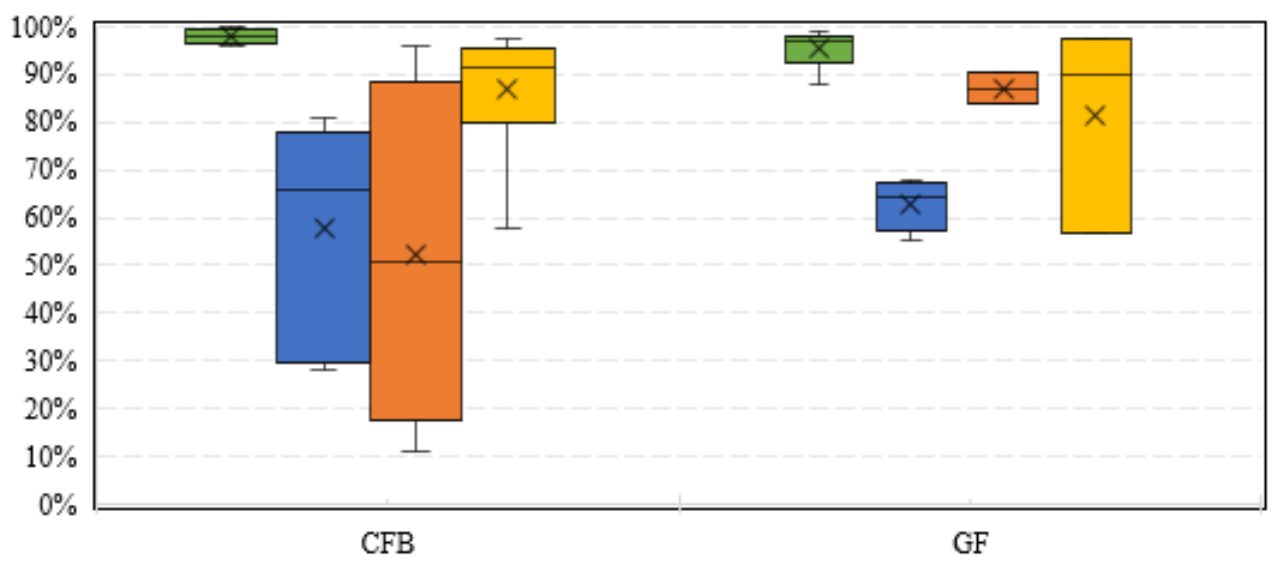

$\mathrm{Hg} \square \mathrm{Cr} \square \mathrm{Pb} \square \mathrm{As}$

Fig. 3. Heavy metal release ratio for GF and CFB boilers.

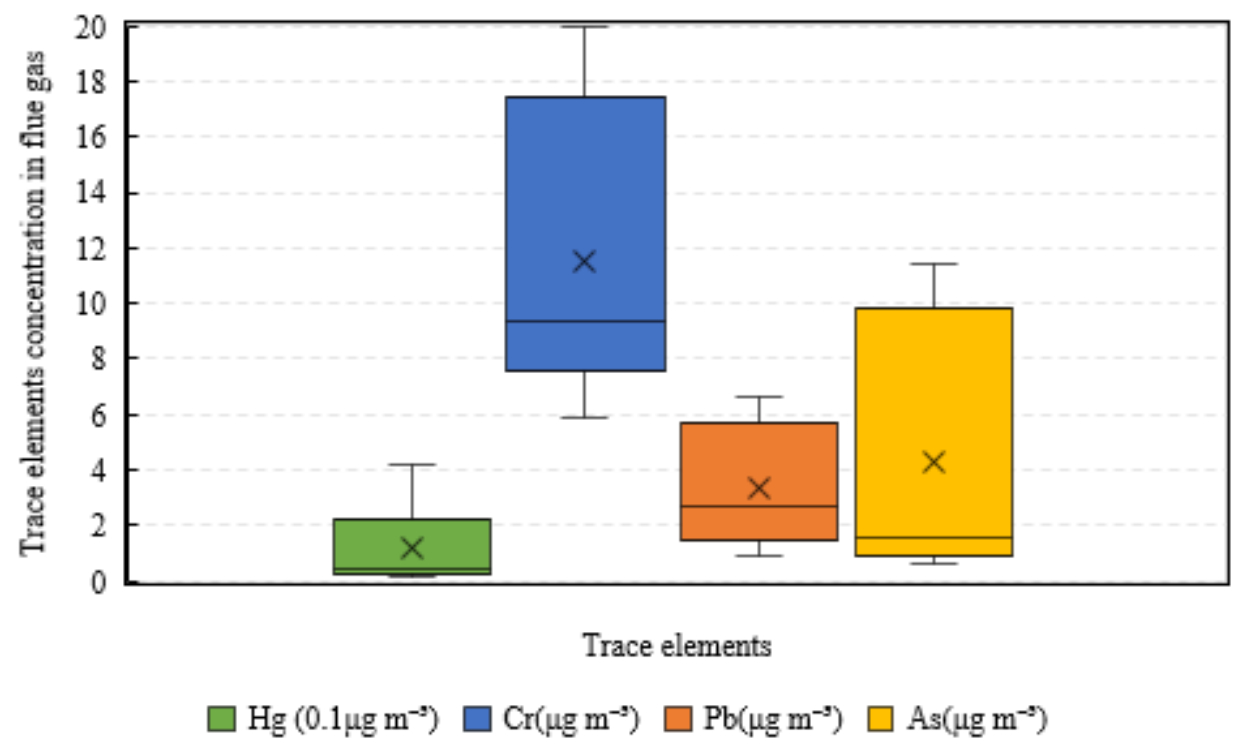

Fig. 4. Trace elements' concentration in the flue gas at the outlet of ULE coal-fired industrial boilers.

96.7-99.0\%, 96.8-99.9\% and 93.7-99.9\%, respectively, and those for non-ULE coal-fired industrial boilers were 20.7$64.3 \%, \quad 96.4-99.2 \%, \quad 93.6-99.5 \%$ and $99.5-99.8 \%$, respectively. The average overall $\mathrm{Hg}$ removal efficiency for the ULE coal-fired industrial boilers was 2.8 times higher than the non-ULE coal-fired industrial boilers. $\mathrm{Hg}$ is divided into three chemical forms, including gaseous elemental mercury $\left(\mathrm{Hg}^{0}\right)$, particle-bound mercury $\left(\mathrm{Hg}_{\mathrm{p}}\right)$ and reactive gaseous mercury $\left(\mathrm{Hg}^{\mathrm{II}}\right)$, accounting for average $56 \%, 10 \%$ and $34 \%$ released from coal combustion sources, respectively (Zhang et al., 2015). With the decreasing temperature of flue gas, hazardous trace elements tend to be adsorbed on particulate matter and subsequently captured by dust removal devices (Zhao et al., 2017; Zheng et al., 2017). Meanwhile, WFGD is the crucial step in the co-benefit mercury control technologies by removing $\mathrm{Hg}^{\mathrm{II}}$ with average $45 \%$ overall mercury removal efficiency (Zhang et al., 2017). ULE coalfired industrial boilers were equipped with WESP and highefficiency WFGD, with high dust removal efficiency and high liquid/gas (L/G) ratio of desulfurization, which enhanced the removal efficiency of $\mathrm{Hg}$ (Zheng et al., 2017).

\section{EFs and Removal Efficiency of Primary Air Pollutants $N O_{x}$}

The requirements of $\mathrm{NO}_{x}$ emission for ULE coal-fired industrial boilers are different in different regions. Under the $\mathrm{O}_{2}$ content of $9 \%$, the emission limit of $\mathrm{NO}_{x}$ for ULE coal-fired boilers is $200 \mathrm{mg} \mathrm{m}^{-3}$ in general and $100 \mathrm{mg} \mathrm{m}^{-3}$ in key region in Shandong Province, while in Beijing-Tianjin-Hebei region the requirement is $50 \mathrm{mg} \mathrm{m}^{-3}$ under the $\mathrm{O}_{2}$ content of $6 \%$. Because of the regional differences of the $\mathrm{NO}_{x}$ emission limit for ULE coal-fired industrial boilers, some denitrification facilities with low efficiency are still used.

The denitrification technologies applied in coal-fired industrial boilers are mainly from the coal-fired power plants due to the similar combustion features, namely SNCR and SCR. Compare with coal-fired power plant, coal-fired industrial boilers were relatively small in capacity. And due 


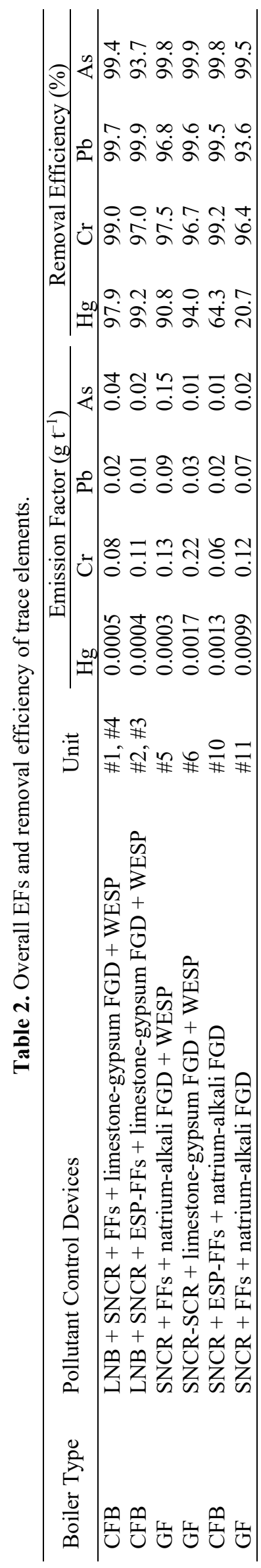

to the limit of initial investment costs, installation space, flue gas temperature and furnace structure, SNCR were widely used in denitrification for coal-fired industrial boilers (Wang, 2018). Meanwhile, to adapt to the low-temperature flue gas emitted from the industrial boilers, oxidation denitrification (OD) with $\mathrm{NaClO}_{2}$ or $\mathrm{O}_{3}$ as the oxidant and sorbent to remove $\mathrm{NO}_{x}$ has been used in recent years (Chien et al., 2000; Hu et al., 2018).

To meet the ultra-low emission limit for $\mathrm{NO}_{x}$, hybrid SNCR-SCR is generally applied in GF boilers to improve the denitrification efficiency, which can pre-reduce the $\mathrm{NO}_{x}$ emission by SNCR and lighten the burden of SCR (Ruan $e t$ al., 2019). Besides, the combination of low- $\mathrm{NO}_{x}$ burner technology (LNB) and SNCR is usually applied in CFB boilers, because of the calcium poisoning of de- $\mathrm{NO}_{x}$ catalysts on SCR and the space limit after furnace (Shang et al., 2013; Wang et al., 2017; Zheng et al., 2017; Ruan et al., 2019).

The $\mathrm{NO}_{x}$ emission concentration for different denitrification technologies obtained in this study are shown in Fig. 5. The average $\mathrm{NO}_{x}$ emission concentrations for LNB + SNCR, SNCR, SNCR-SCR and OD were $37 \mathrm{mg} \mathrm{m}^{-3}, 158 \mathrm{mg} \mathrm{m}^{-3}$, $45 \mathrm{mg} \mathrm{m}^{-3}$ and $111 \mathrm{mg} \mathrm{m}^{-3}$, respectively. The average $\mathrm{NO}_{x}$ emission concentration of LNB + SNCR and SNCR-SCR were significantly lower than that of SNCR and OD. The EFs of $\mathrm{NO}_{x}$ for different denitrification technologies are shown in Table 3. The $\mathrm{NO}_{x}$ EFs of LNB + SNCR, SNCR, SNCRSCR and OD were $0.44 \mathrm{~kg} \mathrm{t}^{-1}, 1.92 \mathrm{~kg} \mathrm{t}^{-1}, 0.49 \mathrm{~kg} \mathrm{t}^{-1}$ and $1.36 \mathrm{~kg} \mathrm{t}^{-1}$, respectively. The efficient working temperature, division and layout of the spray gun, and reducing agent concentrations were the main operating parameters affecting removal efficiency of SNCR (Wang et al., 2017). The $\mathrm{pH}$, solution temperature and degree of oxidation of NO have significant influence on the denitrification of OD (Xiao et al., 2011). With ULE retrofit, the operating parameters of SNCR were optimized, and LNB or SCR were coupled to removal $\mathrm{NO}_{x}$. Therefore, due to unstable coal quality, frequently changed operating loads, unoptimized operating parameters and individual $\mathrm{NO}_{x}$ removal process, the $\mathrm{NO}_{x}$ EFs of SNCR and OD were higher than LNB + SNCR and SNCR-SCR. Since there were no sampling ports at the inlet of the denitrification devices, the $\mathrm{NO}_{x}$ removal efficiency cannot be obtained by the field tests. In this study, $\mathrm{NO}_{x}$ removal efficiency was estimated by the unbated EFs for different types of boilers in Table S4 (CNPSS, 2011). The average $\mathrm{NO}_{x}$ removal efficiency of LNB + SNCR, SNCR, SNCR-SCR and OD were $82 \%, 30 \%, 83 \%$ and $54 \%$ respectively, which are consistent with existing researches (Xiao et al., 2011; Wang et al., 2017; Wang, 2018). The average $\mathrm{NO}_{x}$ removal efficiency of LNB + SNCR and SNCR-SCR was 2.7 times higher than $\eta_{N O x}$ of SNCR and 1.5 times higher than $\eta_{N O x}$ of DO. Therefore, to meet the stricter requirement for $\mathrm{NO}_{x}$ emission, such as $50 \mathrm{mg} \mathrm{m}^{-3}$ under $\mathrm{O}_{2}$ content of $6 \%$ in Beijing-Tianjin-Hebei region, it is recommended to apply LNB + SNCR for CFB boilers and SNCR-SCR for GF boilers.

$\mathrm{SO}_{2}$

WFGD (including limestone-gypsum and natrium alkali) is commonly used in coal-fired industrial boilers to reduce 


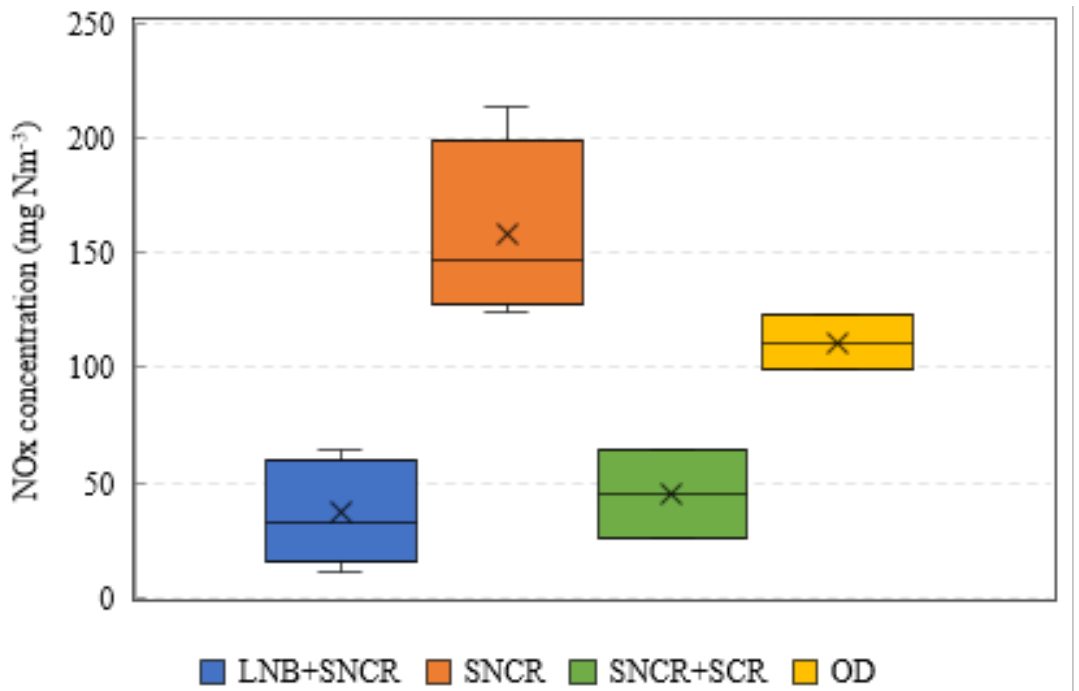

Fig. 5. $\mathrm{NO}_{x}$ emission concentration for different $\mathrm{NO}_{x}$ control devices.

Table 3. $\mathrm{NO}_{x}$ emission factor of different $\mathrm{NO}_{x}$ control devices $\left(\mathrm{kg} \mathrm{t}^{-1}\right)$.

\begin{tabular}{lllll}
\hline & LNB + SNCR & SNCR & SNCR-SCR & OD \\
\hline AM & 0.44 & 1.92 & 0.49 & 1.36 \\
SD & 0.28 & 0.52 & 0.20 & 0.11 \\
NM & 5 & 4 & 2 & 2 \\
MX & 0.77 & 2.76 & 0.69 & 1.46 \\
MI & 0.08 & 1.4 & 0.29 & 1.25 \\
\hline
\end{tabular}

Note: AM—arithmetic mean; ST—-standard deviation; NM—number of samples; MX —-maximal; MI—minimum.

$\mathrm{SO}_{2}$. Liquid gas ratio, $\mathrm{pH}$ value, imported sulfur dioxide concentration and the oxidation of sulfite were main factors for desulfurization efficiency in WFGD system (Chen and $\mathrm{Xu}, 2005$; Zhong et al., 2008). To meet the ultra-low emission limit for $\mathrm{SO}_{2}$, the WFGD can be upgraded by improving the liquid/gas ratio, increasing the spray layer and adding trays in the absorption tower (Lu, 2014; Zhao et al., 2015).

In this study, the inlet and outlet concentration of $\mathrm{SO}_{2}$ and the removal efficiency of WFGD for five ULE coal-fired industrial boilers were obtained. As shown in Table 4, the average $\mathrm{SO}_{2}$ removal efficiency for ULE coal-fired industrial boilers was $96 \%$, which is significantly higher than it for non-ULE coal-fired industrial boilers reported by CNPSS, with the value of $60-80 \%$ (2011). Meanwhile, due to calcium carbonate precipitation by absorbing carbon dioxide from flue gas, natrium alkali WFGD required stricter operating parameters than limestone-gypsum (Mo et al., 2007). In Table 4, the desulfurization efficiency of limestone-gypsum WFGD and natrium alkali WFGD were 97\% and 94\% respectively, which was probably caused by operating conditions, and more field test were needed to identify the variance of desulfurization efficiency.

Table 5 shows the EFs of $\mathrm{SO}_{2}$ for WFGDs based on the field measurements in this study. The average $\mathrm{SO}_{2} \mathrm{EFs}$ for the limestone-gypsum WFGD and the natrium alkali WFGD of ULE coal-fired industrial boilers and the natrium alkali WFGD of non-ULE coal-fired industrial boilers were $0.22 \mathrm{~kg} \mathrm{t}^{-1}, 0.27 \mathrm{~kg} \mathrm{t}^{-1}$ and $0.40 \mathrm{~kg} \mathrm{t}^{-1}$, respectively. In terms of the natrium alkali WFGD, the $\mathrm{SO}_{2}$ EFs of ULE coal-fired industrial boilers reduced by $33 \%$ compared with non-ULE coal-fired industrial boilers. In order to improve desulfurization efficiency, dual-pH value control technology and composite desulfurization tower technology were used in ULE retrofit, leading to higher mass-transfer efficiency and resistance time for sorbent (Guo et al., 2019). Therefore, the desulfurization efficiency of ULE coal-fired industrial boilers improved compared to the three coal-fired industrial boilers with natrium alkali WFGD but without the ULE retrofit.

\section{$P M$}

FFs, due to their high dust removal efficiency and regardless of coal types, have been widely used in coal-fired industrial boilers. Although WFGD can not only effectively reduce $\mathrm{SO}_{2}$ but also remove coarse particles, the removal efficiency of the PM with size $0.2-2 \mu \mathrm{m}$ was relatively low, and even can increase the mass concentration of PM with size 0.094-0.946 $\mu \mathrm{m}$ (Liu et al., 2016; Ruan et al., 2019). Meanwhile, the particle size distributions of GF and CFB were different (Zhao et al., 2017). The mass size distributions (MSDs) of the $\mathrm{PM}_{2.5}$ emitted from GF presented bimodal distribution of the peak existed on $0.12-0.20 \mu \mathrm{m}$ and $>1 \mu \mathrm{m}$ (Li et al., 2009; Wang et al., 2009). Due to different combustion method and combustion temperature, the MSDs of the $\mathrm{PM}_{10}$ emitted from CFB showed no peak (Zhao et al., 2014). To meet the PM ultra-low emission limit and remove the PM produced by WFGD, WESP is installed downstream of the WFGD to capture the ultrafine particulates and other pollutants (Zheng et al., 2017). 
Table 4. $\mathrm{SO}_{2}$ removal efficiency of different desulfurization technologies in ULE coal-fired industrial boilers.

\begin{tabular}{llll}
\hline WFGD type & $\mathrm{C}_{\text {inlet }}\left(\mathrm{mg} \mathrm{Nm}^{-3}\right)$ & $\mathrm{C}_{\text {outlet }}\left(\mathrm{mg} \mathrm{Nm}^{-3}\right)$ & $\eta_{\mathrm{SO} 2}(\%)$ \\
\hline Limestone-gypsum & 226 & 10 & 95.57 \\
& 778 & 14 & 98.24 \\
& 944 & 16 & 98.31 \\
natrium-alkali & 244 & 14 & 94.26 \\
& 815 & 44 & 94.60 \\
\hline
\end{tabular}

Table 5. $\mathrm{SO}_{2}$ EFs of different desulfurization technologies in ULE and non-ULE coal-fired industrial boilers $\left(\mathrm{kg} \mathrm{t}^{-1}\right)$.

\begin{tabular}{llll}
\hline & Limestone-gypsum WFGD (ULE) & natrium-alkali WFGD (ULE) & natrium-alkali WFGD (non-ULE) \\
\hline AM & 0.22 & 0.27 & 0.40 \\
ST & 0.15 & 0.18 & 0.05 \\
NM & 5 & 4 & 3 \\
MX & 0.52 & 0.57 & 0.45 \\
MI & 0.10 & 0.14 & 0.33 \\
\hline
\end{tabular}

Note: AM—arithmetic mean; ST—standard deviation; NM—number of samples; MX—maximal; MI—minimum.

Table 6. PM removal efficiency at different process of APCDs.

\begin{tabular}{|c|c|c|c|c|c|c|c|c|c|}
\hline \multirow{2}{*}{ Unit } & \multicolumn{4}{|c|}{ Dedusting $\left(\mathrm{mg} \mathrm{Nm}^{-3}\right)$} & \multicolumn{4}{|c|}{ Desulfurization + WESP $\left(\mathrm{mg} \mathrm{Nm}^{-3}\right)$} & \multirow{2}{*}{ APCD $\eta$} \\
\hline & Type & $\mathrm{C}_{\text {inlet }}$ & $\mathrm{C}_{\text {out }}$ & $\eta$ & Type & $\mathrm{C}_{\text {inlet }}$ & $\mathrm{C}_{\text {out }}$ & $\eta$ & \\
\hline$\# 1$ & FFs & 26,732 & - & - & limestone/lime-gypsum FGD + WESP & - & 8 & - & $99.97 \%$ \\
\hline$\# 2$ & EFs & 11,952 & 36 & $99.7 \%$ & natrium alkali FGD + WESP & 36 & 8 & $77.7 \%$ & $99.93 \%$ \\
\hline$\# 4$ & FFs & 11,711 & 43 & $99.6 \%$ & limestone/lime-gypsum FGD + WESP & 43 & 5 & $87.3 \%$ & $99.95 \%$ \\
\hline$\# 5$ & FFs & 942 & - & - & natrium alkali FGD + WESP & - & 8 & - & $99.15 \%$ \\
\hline
\end{tabular}

PM removal efficiency of four ULE coal-fired industrial boilers was measured in this study, as shown in Table 6 . The \#1, \#2 and \#4 units were CFB boilers with installed capacities of $75 \mathrm{t} \mathrm{h}^{-1}$, and \#5 unit was GF boiler with installed capacity of $20 \mathrm{t} \mathrm{h}^{-1}$. The mass concentration of PM emitted from CFB were higher than GF, which was mainly produced by fragmentation mechanism and incomplete combustion respectively (Ruan et al., 2019). The average removal efficiency for four ULE coal-fired industrial boilers were $99.75 \%$. And the average removal efficiency for CFB boilers were $99.95 \%$ higher than GF boiler ( $\# 5$ unit) notably (99.15\%). It probably due to the different MSDs and mass concentration for PM emitted from boiler and unstable operating condition for small-capacity boilers (Zhao et al., 2017; Ruan et al., 2019). Meanwhile, the outlet of WFGD had no measuring point; we obtained the average hybrid PM removal efficiency of $82.52 \%$ for WFGD and WESP in \#2 and \#3. Ruan et al. (2019) found the PM removal efficiency of CFB and GF with ULE retrofit were in the range of 98.12-99.56\% and $90.0-93.6 \%$ respectively, which were consistent with this study. Fig. S1 shows the PM removal efficiency and EFs for each ULE coal-fired industrial boilers in this study, and the average PM concentration and EFs were $7.2 \mathrm{mg} \mathrm{m}^{-3}$ and $0.08 \mathrm{~kg} \mathrm{t}^{-1}$, respectively.

\section{CONCLUSION}

This study evaluated nine ULE coal-fired industrial boilers, specifically, the emission and enrichment characteristics of primary air pollutants $\left(\mathrm{PM}, \mathrm{SO}_{2}\right.$ and $\mathrm{NO}_{x}$ ) and trace elements (As, $\mathrm{Cd}, \mathrm{Cr}, \mathrm{Hg}$ and $\mathrm{Pb}$ ), and the removal efficiency of the
APCDs, based on field measurements.

he emission intensities of the ULE boilers for primary pollutants was significantly lower than those of non-ULE coal-fired industrial boilers. The APCDs of the ULE boilers exhibited average overall removal efficiencies of $99.5 \%$, $95.9 \%$ and $81.0 \%$ for $\mathrm{PM}, \mathrm{SO}_{2}$ and $\mathrm{NO}_{x}$, respectively, and the dedusting performance of these boilers was also enhanced by a WFGD + WESP process, which displayed a dedusting efficiency of $85 \%$. Compared with non-ULE boilers, the ULE boilers showed a $37 \%$ higher desulfurization efficiency due to a higher mass-transfer efficiency, longer resistance by the sorbent and optimized operating parameters and a $96 \%$ higher denitrification efficiency due to the coupling of multiple denitrification techniques. Additionally, $\mathrm{NO}_{x} \mathrm{EFs}$ of $0.44 \mathrm{~kg} \mathrm{t}^{-1}$ and $0.49 \mathrm{~kg} \mathrm{t}^{-1}$ were obtained when LNB + SNCR and SNCR-SCR were utilized in the ULE boilers, respectively.

The APCDs used to retrofit the ULE boilers demonstrated higher co-benefit removal efficiencies than those in the nonULE boilers for the trace elements, with average overall removal efficiencies of $95.6 \%, 95.6 \%, 99.3 \%$ and $96.0 \%$ for $\mathrm{Hg}, \mathrm{Cr}, \mathrm{Pb}$ and $\mathrm{As}$, respectively. In particular, the removal efficiency for mercury increased by $180 \%$ due to the speciation of this element and the greater efficiency of the APCDs.

\section{ACKNOWLEDGMENTS}

This work was supported by the National Natural Science Foundation of China (21607008), the National Key Research and Development Program of China (2016YFC0208103), 
Beijing Natural Science Foundation (8192014), Special Project of Application Basic Preface of Wuhan Science and Technology Bureau (No. 2018060401011310), the Building of Innovation Team Plan (IG201804N), the Youth Core Plan (YC201808, YC201810). We also thank the editors and the anonymous reviewers for their valuable comments and suggestions on our paper.

\section{SUPPLEMENTARY MATERIAL}

Supplementary data associated with this article can be found in the online version at http://www.aaqr.org.

\section{REFERENCES}

Bhattacharyya, S., Donahoe, R.J. and Patel, D. (2009). Experimental study of chemical treatment of coal fly ash to reduce the mobility of priority trace elements. Fuel 88: 1173-1184.

Chang, M.B., Huang, C.K., Wu, H.T., Lin, J.J. and Chang, S.H. (2000). Characteristics of heavy metals on particles with different sizes from municipal solid waste incineration. J. Hazard. Mater. 79: 229-239.

Chen, L. and $\mathrm{Xu}, \mathrm{X}$. (2005). Discussion on appropriate liquid/gas ratio for flue gas desulphur-ization process. Environ. Eng. 23: 45-46. (in Chinese)

Chien, T.W. and Chu, H. (2000). Removal of $\mathrm{SO}_{2}$ and $\mathrm{NO}$ from flue gas by wet scrubbing using an aqueous $\mathrm{NaClO}_{2}$ solution. J. Hazard. Mater. 80: 43-57.

China National Environmental Monitoring Centre (NEMC) (2016). Environmental Statistics in 2015. NEMC, Beijing. (in Chinese).

Committee of First National Pollution Source Survey Data Compilation (CNPSS) (2011). Manual of production and discharge coefficient of pollution Source Survey. China Environmental Science Press, Beijing. (in Chinese)

Cornette, J.F., Coppieters, T., Desagher, D., Annendijck, J., Lepaumier, H., Faniel, N., Dyakov, I., Blondeau, J. and Bram, S. (2020). Influence of the dilution system and electrical low-pressure impactor performance on particulate emission measurements from a medium-scale biomass boiler. Aerosol Air Qual. Res. 20: 499-519. doi: 10.4209/aaqr.2019.10.0487.

Duan, L., Xu, G., Liu, D., Chen, X. and Zhao, C. (2012). Experimental on fly ash recirculation with bottom feeding to improve the performance of a circulating fluidized bed boiler co-burning coal sludge. Appl. Energy 95: 295-299.

Gerstle, R.W. and Albrinck, D.N. (1982). Atmospheric emissions of metals from sewage sludge incineration. $J$. Air Pollut. Control Assoc. 32: 1119-1123.

Guo, J., Jiang, R., Zhang, Z., He, S. and Wu, Y. (2019). Ultra-low transformation technologies based on limestonegypsum wet desulfurization. Energy Environ. Prot. 33: 36-38.

Hu, Y., Guo, J., Kong, C., Zhang, H., Zhang, C., Hou, S. and Li, M. (2018). Studies on emission characteristics and monitoring methods of pollutants in flue gas by $\mathrm{NaClO}_{2}$ wet oxidation and denitrification. Ecology Environ. Sci. 27: 1706-1715. (in Chinese)
Li, C., Li, X., Duan, L., Zhao, M., Duan, J. and Hao, J. (2009). Emission Characteristics of $\mathrm{PM}_{10}$ from coal-fired industrial boiler. Environ. Sci. 30: 650-655. (in Chinese)

Li, Z., Hu, Y., Chen, L., Wang, L., Fu, D., Ma, H., Fan, L., An, C. and Liu, A. (2018). Emission Factors of $\mathrm{NO}_{\mathrm{x}}, \mathrm{SO}_{2}$, and $\mathrm{PM}$ for bathing, heating, power generation, coking, and cement industries in Shanxi, China: Based on field measurement. Aerosol Air Qual. Res. 18: 3115-3127. doi: 10.4209/aaqr.2018.08.0282.

Li, Z., Wang, Y., Hu, Y., Chen, L. and Zhu, H. (2019). Emissions of $\mathrm{NO}_{x}, \mathrm{PM}, \mathrm{SO}_{2}$, and VOCs from coal-fired boilers related to coal washing, iron-steel production, and lime and gypsum making in Shanxi, China. Aerosol Air Qual. Res. 19: 2056-2069.

Lin, C.L., Wey, M.Y. and Yu, W.J. (2005). Emission characteristics of organic and heavy metal pollutants in fluidized bed incineration during the agglomeration/ defluidization process. Combust. Flame 143: 139-149.

Liu, X., Xu, Y., Zeng, X., Zhang, Y., Xu, M., Pan, S., Zhang, K., Li, L. and Gao, X. (2016). Field measurements on the emission and removal of $\mathrm{PM}_{2.5}$ from coal-fired power stations: 1. Case study for a $1000 \mathrm{MW}$ ultrasupercritical utility boiler. Energy Fuels 30: 6547-6554.

Lu, H.Y. (2014). Research of the domestic $600 \mathrm{mw}$ supercritical coal-fired units ultra in low emissions of flue gas. Electr. Power Technol. Environ. Prot. 30: 8-11. (in Chinese)

Meij, R. (1994). Trace element behavior in coal-fired power plants. Fuel Process. Technol. 39: 199-217.

Meij, R. and Winkel, H.T. (2007). The emissions of heavy metals and persistent organic pollutants from modern coal-fired power stations. Atmos. Environ. 41: 92629272.

Ministry of Ecological Environment (MEE) (2018) Notice on strengthening boiler energy conservation and environmental protection work. MEE, Beijing. (in Chinese).

Ministry of Environment Protection (MEP) (1996). The determination of particulates and sampling methods of gaseous pollutants emitted from exhaust gas of stationary source (GB/T 16157-1996). MEP, Beijing. (in Chinese).

Ministry of Environment Protection (MEP) (2011). The 12th five-year Plan for the prevention and control of heavy metals pollution. MEP, Beijing. (in Chinese)

Ministry of Environment Protection (MEP) (2013). Explanation for the compilation of boiler air pollutant emission standard. MEP, Beijing. (in Chinese).

Ministry of Environment Protection (MEP) (2014). Emission standard of air pollutants for boiler (GB 132712014). MEP, Beijing. (in Chinese)

Ministry of Environment Protection (MEP) (2017). Stationary source emission-Determination of mass concentration of particulate matter at low concentration-Manual gravimetric method (HJ 836-2017). MEP, Beijing. (in Chinese).

Mo, J., Wu, Z., Cheng, C., Guan, B. and Zhao, W. (2007). Oxidation inhibition of sulfite in dual-alkali flue gas desulfurization system. J. Environ. Sci. 19: 226-231.

National Bureau of Statistics (NBS) (2016). China Energy 
Statistical Yearbook. China Statistics Press, Beijing. (in Chinese).

Ruan, R., Xu, X., Tan, H., Zhang, S., Lu, X., Zhang, P., Han, R. and Xiong, X. (2019). Emission characteristics of particulate matter from two ultra-low emission coal-fired industrial boilers in Xi'an, China. Energy Fuels 33: 1944 1954.

Shandong Provincial Environmental Protection Department (SEPD) (2015). Shandong Guidelines on accelerating the promotion of ultra-low emissions from coal-fired boilers. SEPD, Shandong. (in Chinese).

Shang, X., Chen, J., Yao, Y. and Hu, G. (2013). Study on calcium poisoning of commercial SCR de- $\mathrm{NO}_{\mathrm{x}}$ catalyst. Chin. J. Environ. Eng. 7: 624-630. (in Chinese)

Tian, H.Z., Zhu, C.Y., Gao, J.J., Cheng, K., Hao, J.M., Wang, K., Hua, S.B., Wang, Y. and Zhou, J.R. (2015). Quantitative assessment of atmospheric emissions of toxic heavy metals from anthropogenic sources in China: historical trend, spatial distribution, uncertainties, and control policies. Atmos. Chem. Phys. 15: 10127-10147.

Tian, H.Z., Zhu, C.Y., Hao Y., Gao, J.J., Hao, J.M., Wang, Y., Hua. S., Wang, K. and Liu, H. (2018). A highresolution emission inventory of anthropogenic trace elements in Beijing-Tianjin-Hebei (BTH) region of China. Atmos. Environ. 191: 452-462.

Wang, F., Wang, D. and Feng, Q. (2017). Study on lownitrogen combustion and SNCR combined denitrification system of CFB boiler under ultra-low emission situation. Power Gener. Air Condition 38: 6-10. (in Chinese)

Wang, J. (2018). Application and comparison of SCR, SNCR and SNCR/SCR flue gas denitration technology. Electr. Power Technol. Environ. Prot. 34: 35-36.

Wang, S., Zhao, X., Li, X., Wei, W. and Hao, J. (2009). Emission characteristics of fine particles from grate firing boilers. Environ. Sci. 30: 963-968. (in Chinese)

Wu, B., Tian, H., Hao, Y., Liu, S., Liu, X., Liu, W., Bai, X., Liang, W., Lin, S., Wu, Y., Shao, P., Liu, H. and Zhu, C. (2018). Effects of wet flue gas desulfurization and wet electrostatic precipitators on emission characteristics of particulate matter and its ionic compositions from four $300 \mathrm{MW}$ level ultralow coal-fired power plants. Environ. Sci. Technol. 52: 14015-14026.

Wu, B., Tian, H., Hao, Y., Liu, S., Sun, Y., Bai, X., Liu, W., Lin, S., Zhu, C., Hao, J., Luo, L., Zhao, S. and Guo, Z. (2020) Refined assessment of size-fractioned particulate matter $\left(\mathrm{PM}_{2.5} / \mathrm{PM}_{10} / \mathrm{PM}_{\text {total }}\right)$ emissions from coal-fired power plants in China. Sci. Total Environ. 706: 135735.

Xiao, L., Cheng, B., Mo, J., Wang, H. and Wu, Z. (2011). Removal of $\mathrm{NO}$ and $\mathrm{SO}_{2}$ from flue gas by wet scrubbing using aqueous $\mathrm{NaClO}$ solution. Acta Sci. Circumst. 31: 1175-1180. (in Chinese)

Xu, H., Luo, Z.Y., Wang, T., Wang, P., Gao, X., Shi, Z. and Cen, K. (2004). Studies on the characteristics of aerosol and trace metals emitted from a CFB coal-fired power plant. Acta Sci. Circum. 3: 515-519. (in Chinese)

Yao, S., Cheng, S., Li, J., Zhang, H., Jia, J. and Sun, X. (2019). Effect of wet flue gas desulfurization (WFGD) on fine particle $\left(\mathrm{PM}_{2.5}\right)$ emission from coal-fired boilers. $J$. Environ. Sci. 77: 32-42.
Yue, T., Zhang, X., Wang, C., Zuo, P., Tong, Y., Gao, J., Xue, Y., Tong, L., Wang, K. and Gao, X. (2018). Environmental impacts of the revised emission standard for air pollutants for boilers during the heating season in Beijing, China. Aerosol Air Qual. Res. 18: 2853-2864. doi: 10.4209/aaqr.2018.02.0046.

Zhang, L., Zhuo, Y., Chen, L., Xu, X. and Chen, C. (2008). Mercury emissions from six coal-fired power plants in China. Fuel Process. Technol. 89: 1033-1040.

Zhang, L., Wang, S., Wang, L., Wu, Y., Duan, L. and Wu, Q. (2015). Updated emission inventories for speciated atmospheric mercury from anthropogenic sources in china. Environ. Sci. Technol. 49: 3185-3194.

Zhang, L., Wang, S., Wu, Q., Wang. F., Lin, C., Zhang, L., Hui, M., Yang, M., Su, H. and Hao, J. (2016) Mercury transformation and speciation in flue gases from anthropogenic emission sources: a critical review. Atmos. Chem. Phys. 16: 2417-2433.

Zhang, Y., Yang, J., Yu, X., Sun, P., Zhao, Y., Zhang, J., Chen, G., Yao, H. and Zheng, C.H. (2017). Migration and emission characteristics of $\mathrm{Hg}$ in coal-fired power plant of china with ultra-low emission air pollution control devices. Fuel Process. Technol. 158: 272-280.

Zhang, Y., Zheng, C., Liu, S., Qu, R., Yang, Y., Zhao, H., Yang, Z., Zhu, Y. and Gao, X. (2019). An investigation of $\mathrm{SO}_{3}$ control routes in ultra-low emission coal-fired power plants. Aerosol Air Qual. Res. 19: 2908-2916. doi: 10.4209/aaqr.2019.09.0425.

Zhao, S., Duan, Y., Yao, T., Liu, M., Lu, J., Tan, H., Wang, $\mathrm{X}$. and $\mathrm{Wu}, \mathrm{L}$. (2017). Study on the mercury emission and transformation in an ultra-low emission coal-fired power plant. Fuel 199: 653-661.

Zhao, Y., Wang, S., Nielsen, C. P., Li, X. and Hao, J. (2010). Establishment of a database of emission factors for atmospheric pollutants from Chinese coal-fired power plants. Atmos. Environ. 44: 1515-1523.

Zhao, Y., Ma, S., Yang, J., Zhang J. and Zheng, C. (2015). Status of ultra-low emission technology in coal-fired power plant. J. China Coal. Soc. 40: 2629-2640. (in Chinese)

Zhao, Z., Du, Q., Zhao, G., Gao, J., Dong, H., Cao, Y., Han, Q., Yuan, P. and Su, L. (2014). Fine particle emission from an industrial coal-fired circulating fluidized-bed boiler equipped with a fabric filter in China. Energy Fuels 28: 4769-4780.

Zhao, Z., Du, Q., Dong, H., Su, L., Zhao, G., Lv, D., Wang, M., Gao, J., Guo, X., Xu, L. and Zhao, L. (2017). Influence of wet flue gas desulfurization devices on $\mathrm{PM}_{2.5}$ emission characteristics of coal-fired boilers. J. Chem. Ind. Eng. (China) 68: 4261-4271. (in Chinese)

Zheng, C., Wang, L., Zhang, Y., Zhang, J., Zhao, H., Zhou, J., Gao, X. and Cen, K. (2017). Partitioning of hazardous trace elements among air pollution control devices in ultra-low-emission coal-fired power plants. Energy Fuels 31: 6334-6344.

Zhong, Y., Gao, X., Luo, Z., Wang, H., Huo, W. and Cen, K. (2008). Factors influencing desulfurization efficiency of wet flue gas desulfurization system. J. Zhejiang Univ. (Eng. Sci.) 42: 890-894. (in Chinese) 
Zhu, F.H., Wang, L.Q. and Zhao, X. (2014) Analysis on technology-economy and environment benefit of ultralow emission from coal-fired power units. Environ. Prot. 42: 28-33. (in Chinese).
Received for review, January 17, 2020

Revised, March 4, 2020

Accepted, March 5, 2020 